\title{
Physiological responses of Pseudomonas putida KT2442 to phosphate starvation
}

\author{
Leo Eberl, ${ }^{1}$ Michael Givskov, ${ }^{1}$ Claus Sternberg, ${ }^{1}$ Søren Møller, ${ }^{1}$ \\ Gunna Christiansen ${ }^{2}$ and Søren Molin ${ }^{1}$
}

Author for correspondence: Søren Molin. Tel: +454525 2513. Fax: +4545887328.

e-mail : sm@1m.dtu.dk

1 Department of

Microbiology, The

Technical University of

Denmark, DK-2800 Lyngby,

Copenhagen, Denmark

2 Institute of Medical

Microbiology, The

Bartholin Building,

University of Aarhus, DK-

8000 Århus C, Denmark
The physiological responses of Pseudomonas putida KT2442 to phosphate starvation were examined with respect to cell morphology, qualitative demonstration of the accumulation of the intracellular storage component poly-3-hydroxyalkanoate (PHA), cellular ATP and ribosome content, and the rate of total protein synthesis. Upon prolonged incubation under phosphatelimiting conditions, the number of viable cells decreased by two to three orders of magnitude during the first 3 weeks. However, after this decline, viability of the cultures remained remarkably constant for many weeks. The cells remained rod-shaped under phosphate starvation conditions with a tendency to swell in parallel with the accumulation of PHA. Protein synthesis and ribosome concentration were gradually reduced, and ATP levels dropped to very low values after the onset of starvation; later, however, there was a return to near-normal ATP concentrations. Evidence was obtained that the strong selective pressure imposed by phosphate deprivation forces the selection of mutants with a competitive advantage. These mutants are able to grow, possibly utilizing nutrients derived from dead cells, and eventually take over the cultures. One frequently encountered mutant formed smaller colonies on rich solidified medium and displayed an altered cell morphology. This mutant was isolated and further characterized. By employing a

bioluminescence-based marker system, we demonstrated that this mutant is able to replace wild-type cells in mixed culture experiments. Thus, long-term phosphate-deprived cultures represent dynamic regimes that can undergo population shifts.

Keywords: Pseudomonas putida, phosphate starvation, cellular ATP content, protein synthesis rates, population take over

\section{INTRODUCTION}

Phosphorus is an essential element for bacteria. In spite of its relative abundance in nature, phosphate is often found to be a growth-limiting factor for many organisms since it is mainly found naturally as insoluble salts. In soils, phosphate is retained as $\mathrm{Ca}, \mathrm{Fe}$ or $\mathrm{Al}$ precipitates or by adsorption to these cations at the surface of soil minerals (Sample et al., 1980). Accordingly, De Weger et al. (1993) have demonstrated that cells of a Pseudomonas putida reporter strain that responds to low levels of phosphate by the production of $\beta$-galactosidase, suffer from phosphate limitation when grown under gnotobiotic conditions in various root rhizospheres or in bulk soil. To deal with

Abbreviations: DVC, direct viable count; PHA, poly-3-hydroxyalkanoate. phosphate-limiting environments, bacteria have evolved systems for the efficient uptake and degradation of extracellular phosphorus sources (Wanner, 1987). In $P$. aeruginosa, phosphate limitation induces the synthesis of several proteins that include alkaline phosphatase, an outer-membrane channel-forming protein, a binding protein for phosphate, and two haemolysins (Hancock et al., 1982; Ostroff \& Vasil, 1987; Poole \& Hancock, 1984). Furthermore, cells of $P$. aeruginosa starved for phosphorus exhibit a strong chemotactic response to phosphate (Kato et al., 1992). Phosphate taxis as well as the expression of several genes that are responsive to phosphate limitation appear to be under the control of the pho regulon of $P$. aeruginosa (Anba et al., 1990).

Our previous work describing the physiology of starved and stressed cells of $P$. putida strain KT2442 has mainly 
focused on carbon starvation (Givskov et al., 1994a). However, we noted that under the condition of sulphur or phosphate deprivation, this strain exhibited very poor starvation survival. In contrast, cells starved for nitrogen or carbon were found to be fully viable for at least 1 month. It has also been demonstrated that at least 56 proteins are induced during phosphate starvation, of which 14 appear to be also responsive to carbon starvation. Finally, a core set of eight proteins has been identified that are induced during starvation for any of the three macronutrients (Givskov et al., 1994b).

In this paper, we describe the responses of $P$. putida KT2442 to phosphate starvation with respect to cell morphology, macromolecular content, and rates of total protein synthesis. We demonstrate that after 3 weeks of phosphate starvation, during which more than $99 \%$ of the initial population no longer form colonies on plates, mutants with a competitive advantage are selected that are able to re-initiate growth and eventually take over the cultures. The results presented strongly suggest that phosphate-deprived cultures undergo population shifts.

\section{METHODS}

Organism, cultivation and starvation conditions. The $P$. putida strain KT2442 used in this study is a rifampicin-resistant, TOL-plasmid-cured derivative of $P$. putida mt-2 (Bagdasarian et al., 1981). P. putida GPp104 is a mutant strain of KT2442 that is defective in the synthesis of the polyester poly-3-hydroxyalkanoate (PHA) (Huisman et al., 1991). Cells were grown in either MOPS (Neidhardt et al., 1974) or AB (Clark \& Maaløe, 1967) minimal medium supplemented with either $0.4 \%$ glucose or $0.3 \%$ citrate. Starvation regimes were set up after harvesting an exponentially growing culture (about $4 \times 10^{8}$ cells $\mathrm{ml}^{-1}$ ) by centrifugation followed by resuspension in preheated medium depleted of the appropriate nutrient. Alternatively, starvation was accomplished by exhaustion of the carbon or phosphate source. Starvation for carbon was obtained by exhaustion of $0.02 \%$ glucose or $0.03 \%$ citrate in MOPS medium (resulting in cell densities of about $5 \times 10^{8}$ c.f.u. $\mathrm{ml}^{-1}$ ) and phosphate starvation was obtained by exhaustion of $8 \mu \mathrm{M} \mathrm{K} \mathrm{K}_{2} \mathrm{HPO}_{4}$ in MOPS medium (resulting in cell densities of about $1 \times 10^{8}$ c.f.u. $\mathrm{ml}^{-1}$ ) supplemented with $0.4 \%$ glucose. Growth and starvation of $P$. putida cells were carried out at $30^{\circ} \mathrm{C}$ and the cell mass of the cultures was measured spectrophotometrically at $450 \mathrm{~nm}$.

Construction and detection of bioluminescent strains. To distinguish wild-type from mutant cells in the course of the mixed culture experiments, bioluminescent derivatives of the two strains were constructed. The hybrid transposon mini- $\operatorname{Tn} 5$ lux $A B$ res-npt-res was inserted randomly into the chromosome of the two target strains using the triparental mating procedure described by Kristensen et al. (1995). Since this hybrid transposon carries the promoterless luciferase genes from Vibrio barveyi, the luminescence is a measure of the strength of adjacent promoters. Colonies of random insertion mutants grown on selective plates were screened for strong light emission after $n$ decanal was provided in the lid of the Petri dish. Bioluminescence was visualized using an extremely sensitive photoncounting camera (ARGUS-50 system with a C2400-47 camera, Hamamatsu Photonics). One very bright mutant of each strain [KT2442 as well as PSOM (phosphate starvation originating mutant)] was selected and used for all subsequent mixed culture studies where they were used in combination with their respective non-luminescent counterpart.
Viability measurement. Viability of starved cultures was assessed by plating serial dilutions onto solidified LB medium. The direct viable count (DVC) method (Kogure et al., 1979) was employed using nalidixic acid and yeast extract at final concentrations of $20 \mu \mathrm{g} \mathrm{ml}^{-1}$ and $0.25 \%$, respectively, to determine the proportion of viable cells.

Measurement of protein synthesis. The rate of total protein synthesis was determined as the rate of $\left[{ }^{14} \mathrm{C}\right]$ leucine incorporation into trichloracetic acid (TCA)-insoluble material. A subvolume of the bacterial culture was taken and added to onetenth volume of $\left[{ }^{14} \mathrm{C}\right.$ leucine [diluted to $5 \mu \mathrm{Ci} \mathrm{ml} l^{-1}, 5.4 \mathrm{Ci}$ $\left.\mathrm{mmol}^{-1}\left(185 \mathrm{kBq} \mathrm{ml}^{-1}, 200 \mathrm{GBq} \mathrm{mmol}^{-1}\right)\right]$; the labelling period was $15 \mathrm{~min}$. Samples ( $200 \mu \mathrm{l} \mathrm{each})$, in duplicate, were removed at different times after addition of the isotope, and precipitation of macromolecules was performed overnight on ice in $5 \%(\mathrm{v} / \mathrm{v})$ TCA supplemented with $1 \mu \mathrm{g}$ unlabelled leucine $\mathrm{ml}^{-1}$. The precipitates were collected on membrane filters, washed with $5 \%$ TCA supplemented with $1 \mu \mathrm{g}$ unlabelled leucine $\mathrm{ml}^{-1}$, washed with ethanol and dried. Five millilitres of scintillation liquid was added prior to counting in a scintillation counter.

Determination of cell size and ribosome content. The content of ribosomes per cell was estimated by in situ rRNA hybridization, and cell volumes were determined by flow cytometry as described previously (Givskov et al., 1994a). Briefly, cells were fixed in $3 \%(\mathrm{v} / \mathrm{v})$ paraformaldehyde and then hybridized with a rhodamine-labelled probe, EUB338, targeting the eubacterial domain. Images of fluorescing cells were captured with a charge-coupled device camera ( $\mathrm{CH} 250$; Photometrics) mounted on a Carl Zeiss Axioplan microscope. These images were subsequently subjected to image analysis using the CELLSTAT software (Møller et al., 1995) to quantify the light intensity of single cells reflecting their ribosomal content. For the determination of cell size, the forward light scatter was measured on an Argus fluorescence-based flow cytometer (Skatron).

Measurement of cellular ATP content. The amount of ATP in cells was determined by the method of Holm-Hansen \& Booth (1966). Adenylates were extracted by rapidly injecting $100 \mu \mathrm{l}$ samples of cell cultures into boiling $20 \mathrm{mM}$ Tris $/ \mathrm{HCl}$ buffer $(\mathrm{pH}$ 7.5). The cells were extracted for $5 \mathrm{~min}$ and then immediately frozen for subsequent analysis. An equivalent volume of sterilefiltered culture supernatant was also extracted at each sampling period to monitor the occurrence of extracellular ATP. ATP concentrations of the extracts were determined using a firefly luciferase-based ATP assay kit (Boehringer) according to the specifications of the manufacturer. Light emission was measured in a Turner TD-20e (Turner Designs) apparatus. Since ATP concentrations in cell-free extracts were always below the detection limit of the assay, no corrections were applied.

Electron microscopy. Preparation of cells for electron microscopy was performed as described previously (Klemm \& Christiansen, 1987). Samples $(25 \mu \mathrm{l})$ of bacterial cultures were placed on top of a parlodion carbon-coated glow discharge copper grid ( $300 \mathrm{mesh}$ ) for $30 \mathrm{~s}$. The grids were then washed with three drops of buffered saline followed by staining with three drops of $1 \%(\mathrm{v} / \mathrm{v})$ phosphotungstic acid $(\mathrm{pH} 7.0)$ and blotted dry. The grids were examined in a JEOL $100 \mathrm{~B}$ electron microscope.

\section{RESULTS}

\section{Changes in cell morphology and the fate of carbon during phosphate starvation}

One of the characteristic changes that takes place when $P$. putida KT2442 is exposed to carbon limitation is the formation of small, almost spherical cells as a result of 


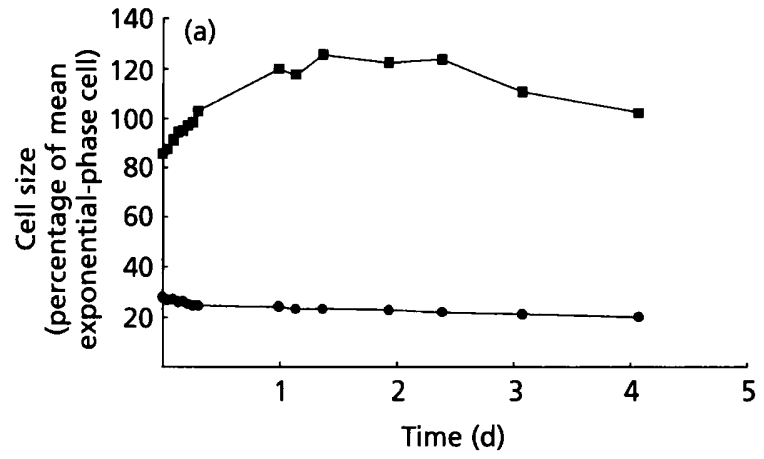

(b)

(c)

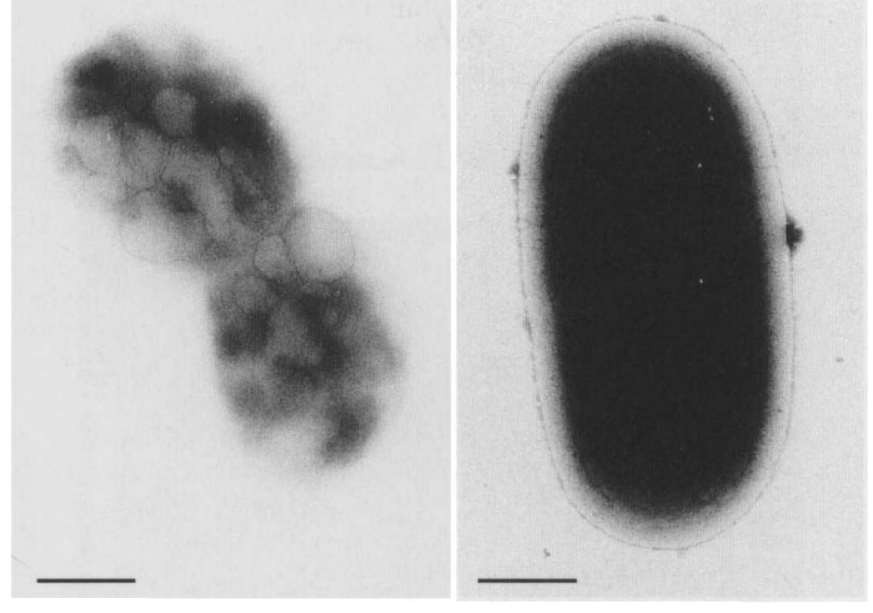

Fig. 1. Changes in cell size and morphology during phosphate starvation. Cells were grown in MOPS minimal medium such that they exhausted the available carbon or phosphate source. Time zero represents values obtained from overnight run-outs. (a) Changes in cell size as measured by flow cytometry during phosphate ( $\boldsymbol{G})$ and carbon (O) deprivation. Electron micrographs of (b) wild-type P. putida KT2442 and (c) the PHA derivative GPp104 after $3 \mathrm{~d}$ of phosphate starvation. Bar, $0.3 \mu \mathrm{m}$.

reductive cell divisions (Fig. 1a and Givskov et al., 1994a). In contrast to carbon deprivation, phosphate-starved cells retain their rod-shape, and they swell significantly (Fig. 1a). Since strain KT2442 is capable of synthesizing the biopolymer PHA, not only under nitrogen-limiting conditions but even during exponential growth (Huisman et al., 1989; Huijberts et al., 1994), we speculated that the observed increase in cell size could be attributed to the accumulation of this intracellular storage compound. Indeed, phase-contrast microscopy revealed that cells exhausted for phosphate accumulated small coalescent granules characteristic of $\mathrm{PHA}$, whereas a mutant derivative of KT2442, P. putida GPp104, that is defective in the synthesis of the polymer, did not (data not shown). The presence of lipid-like reserve material during phosphate starvation was further confirmed by electron microscopy as large, electron-lucent granules or vacuoles in wild-type cells, but not in GPp104 cells (Fig. 1b, c).

The accumulation of large amounts of storage material could also explain the finding that even though cell

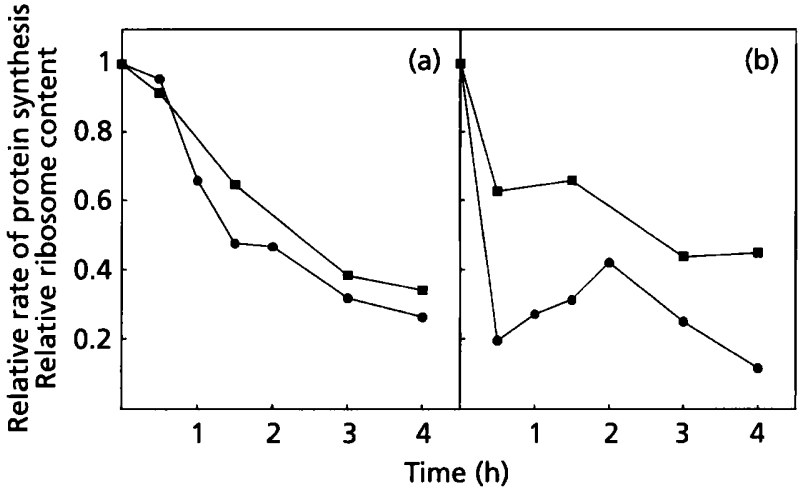

Fig. 2. Relative rates of protein synthesis (O) and relative ribosome content ( $\square$ ) during (a) phosphate and (b) carbon starvation. The rate of protein synthesis as well as the in situ rRNA hybridization signal of a growing culture immediately before the cells were harvested and resuspended in appropriate starvation medium were arbitrarily set to 1 . The graphs represent typical data obtained from three replicates.

growth had ceased, all available carbon in the culture (glucose or citrate) was utilized during the first $3 \mathrm{~d}$ of phosphate starvation. However, reactivation experiments, in which either phosphate or carbon, or both were added to the cultures, clearly demonstrated that addition of phosphate alone is sufficient for re-initiation of growth (data not shown). The same results were also obtained with long-term starved cultures (up to $74 \mathrm{~d}$, see below), indicating that these were truly phosphate-limited, containing sufficient energy-rich compounds to allow continued growth after re-addition of phosphate.

\section{Changes in rates of protein synthesis and rRNA content following onset of phosphate deprivation}

When an exponentially growing culture of $P$. putida KT2442 was shifted to a carbon-free medium, an immediate decline in the rate of total protein synthesis was observed, followed by a slight reactivation and a subsequent steady decrease during prolonged starvation (Fig. $2 \mathrm{~b}$ and Givskov et al., 1994a). Phosphate deprivation also resulted in a reduction of the protein synthesis rate which, however, occurred more gradually. Moreover, the second peak in protein synthesis, which is characteristic for the stringent response (Nyström et al., 1992), was not observed (Fig. 2a). In the same experiment we also monitored the cellular rRNA content by employing in situ hybridization to $16 \mathrm{~S}$ rRNA of fixed cells. Following the onset of phosphate starvation, the decrease in hybridization signal closely followed the reduction in protein synthesis rate (Fig. 2a), indicating that the rate of protein synthesis matches the cellular capacity to make proteins (i.e. the level of ribosomes). After $24 \mathrm{~h}$ of starvation, the rate of protein synthesis was reduced much more than the hybridization signal (not shown). The cellular rRNA content had declined to $0 \cdot 1$, whereas the rate of protein synthesis per living cell (c.f.u.) had declined to 0.02 of the rate during growth (data not shown). A similar calculation showed that cells starved for carbon for $24 \mathrm{~h}$ had lost 


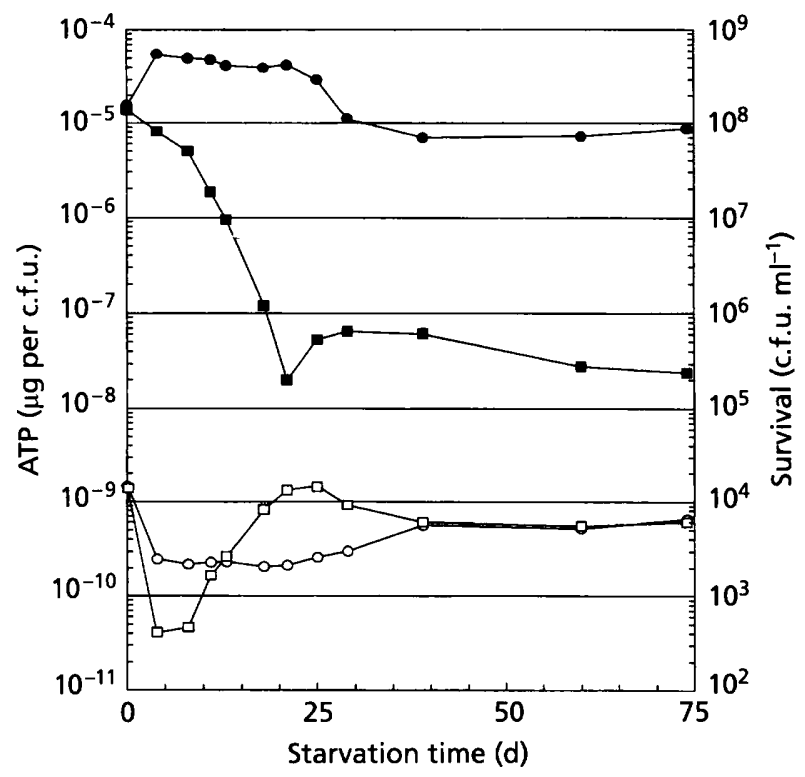

Fig. 3. Long-term survival $(\square, 0)$ and cellular ATP content $(\square, O)$ of $P$. putida KT2442 during phosphate $(\square, \square)$ and carbon starvation $(0,0)$. Values represent mean values of three independent experiments.

approximately $80 \%$ of their rRNA and synthesized protein at a rate of 0.05 compared to their exponentially growing counterparts. This indicates that cells starved for $1 \mathrm{~d}$ or longer contain a surplus of ribosomes relative to that expected from the rate of total protein synthesis.

\section{Changes in viability and ATP content during long- term phosphate starvation}

To investigate the survival of $P$. putida KT2442 during long-term phosphate starvation, cells were grown in minimal medium such that they exhausted the phosphate, and viable counts (c.f.u.) as well as ATP concentrations of the cultures were subsequently determined over a period of $74 \mathrm{~d}$ (Fig. 3). With the phosphate concentration used, the cultures achieved cell densities of approximately $1 \times 10^{8}$ c.f.u. $\mathrm{ml}^{-1}$ corresponding to an $\mathrm{OD}_{450}$ of $0 \cdot 3$. Viability (c.f.u.) of the cultures dropped two to three orders of magnitude during the first 3 weeks, after which the viable counts increased slightly and then remained constant for at least 8 months (longest time tested).

Exponential-phase cells of KT2442 contained $1.4 \times 10^{-9}$ $\mu \mathrm{g}$ ATP per cell. When cells were depleted for phosphate, the ATP level per viable cell decreased to about $3 \%$ of the initial level within $3 \mathrm{~d}$. Surprisingly, for cells starved for glucose, the ATP concentration per c.f.u. was found to be 5-8 times higher than in cells in the early phase of phosphate starvation. However, in the course of phosphate starvation the concentration of ATP per viable cell increased steadily until, at its peak after approximately 25 $\mathrm{d}$, it reached a level close to that found in growing cells (Fig. 3). Thereafter, the concentration of ATP per c.f.u. decreased to a final level comparable to that found in cells starved for carbon.
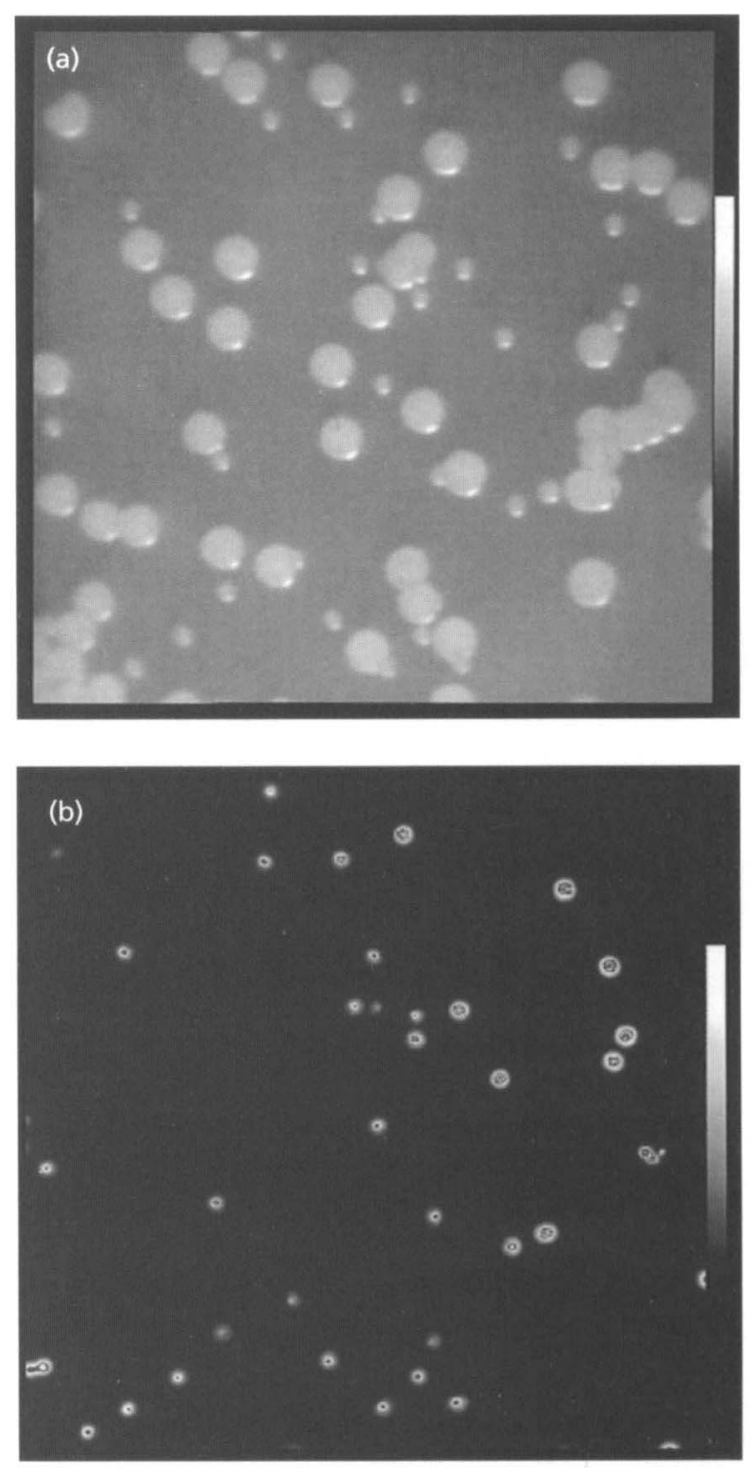

Fig. 4. Differences in colony size between $\mathrm{KT} 2442$ and PSOM (a). Example of the use of the $V$. harveyi luxAB genes to distinguish between wild-type and mutant cells (b). The latter contain the marker genes in the picture shown. The image was taken with a photon-counting camera after $n$-decanal was provided in the lid of the Petri dish.

It has been demonstrated that cells entering a viable but non-culturable state, i.e. becoming non-platable, may maintain their intracellular levels of ATP (Dawe \& Penrose 1978; Roth et al., 1988). In such a situation, the number of actively respiring cells rather than the c.f.u. would be the correct denominator for calculating the changes in ATP per cell, as has been pointed out by Kurath \& Morita (1983). We therefore determined the DVC of the starved culture throughout the entire period of the experiment. However, at no time could significant differences between c.f.u. and DVC be observed (data not shown), indicating that cells of $P$. putida KT2442 starved for carbon or phosphate at $30^{\circ} \mathrm{C}$ do not enter a viable but non-culturable state. 

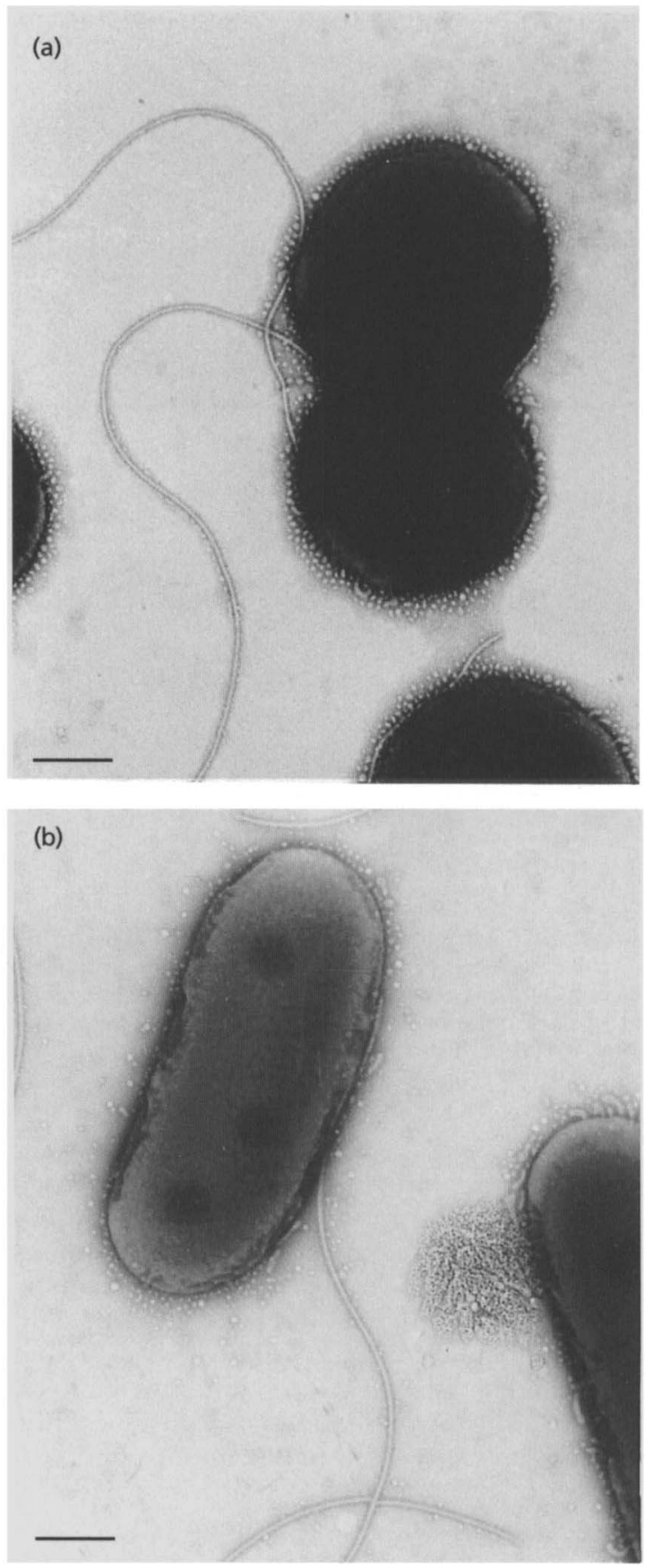

Fig. 5. Different morphotypes of (a) KT2442 and (b) PSOM after $3 \mathrm{~d}$ of carbon starvation. Bar, $0.3 \mu \mathrm{m}$.

\section{Isolation and characterization of a mutant with a competitive advantage under phosphate-limiting conditions}

We frequently observed that the increase in c.f.u. after approximately 3 weeks of phosphate starvation (Fig. 3) coincided with the appearance of small colonies when culture samples were spread on LB plates. After even longer periods of starvation these small colonies became increasingly dominant and eventually replaced the wild- type-sized colonies. The size of these colonies remained small, after restreaking, relative to colonies of the wildtype strain (Fig. 4), indicating that this phenotype was caused by mutation(s) rather than a reversible physiological adaptation. This was further supported by the observation that cells originating from such small colonies were morphologically distinct from wild-type cells, even after repeated cycles of exponential growth. Cells from small colonies grown exponentially in $\mathrm{AB}$ minimal medium were significantly thinner than KT2442 wildtype cells, but they were equal in cell length, and this difference in cell shape could also be observed during phosphate starvation (data not shown). However, the difference in cell morphology was most evident during carbon starvation. Under this condition, wild-type cells became much smaller and almost spherical, whereas mutant cells decreased only slightly in size and remained clearly rod-shaped (Fig. 5). One such mutant was selected, designated PSOM (see Methods), and this clone was used in all subsequent studies.

The smaller colony size of the mutant strain is also reflected in a reduced growth rate. $P$. putida KT2442 grown at $30{ }^{\circ} \mathrm{C}$ in $\mathrm{AB}$ minimal medium supplemented with $0.4 \%$ glucose proliferated with a generation time of $62 \mathrm{~min}$ in contrast to $85 \mathrm{~min}$ for PSOM. Similarly, the doubling time was increased from 55 (wild-type) to 75 min (mutant) using $0.2 \%$ citrate as carbon source (data not shown).

Since mutant cells dominate long-term phosphate-starved cultures, we speculated that PSOM could exhibit an increased ability to survive phosphate deprivation. However, no significant difference in starvation survival between the mutant and wild-type strains could be observed (Fig. 6a). We next investigated whether PSOM has a competitive advantage over KT2442 that would allow domination in phosphate-limited mixed cultures of the two strains. To distinguish the two strains, either mutant or wild-type cells carried the npt (neomycin phosphotransferase) resistance gene from $\operatorname{Tn} 5$ together with the lux $A B$ genes from Vibrio harveyi inserted into the chromosome (see Methods for details). Thus, in these mixed culture experiments one of the strains is kanamycinresistant and, in addition, emits light in the presence of the luciferase substrate, decanal (Fig. 4b). The presence of the $\mathrm{Km}^{\mathrm{R}}$ marker or the lux $A B$ genes per se did not affect starvation survival (data not shown).

Cultures of both strains were starved for phosphorus for $2 \mathrm{~d}$ prior to mixing and the viable counts of each population were subsequently followed by plating on appropriate media as well as by viewing plates with a light-sensitive camera after addition of decanal to the lid of the Petri dish. Regardless of whether the cells from the two cultures were mixed in equal numbers, or the mutant cells were introduced as a minority population in the wildtype culture, the mutant cells took over the population (Fig. 6b, c). Interestingly, during the first 3 weeks of starvation both populations decreased in c.f.u., and upon prolonged starvation the wild-type strain continued to decrease, whereas the mutant increased. Similarly, when cells of the two strains were mixed in equal numbers and 


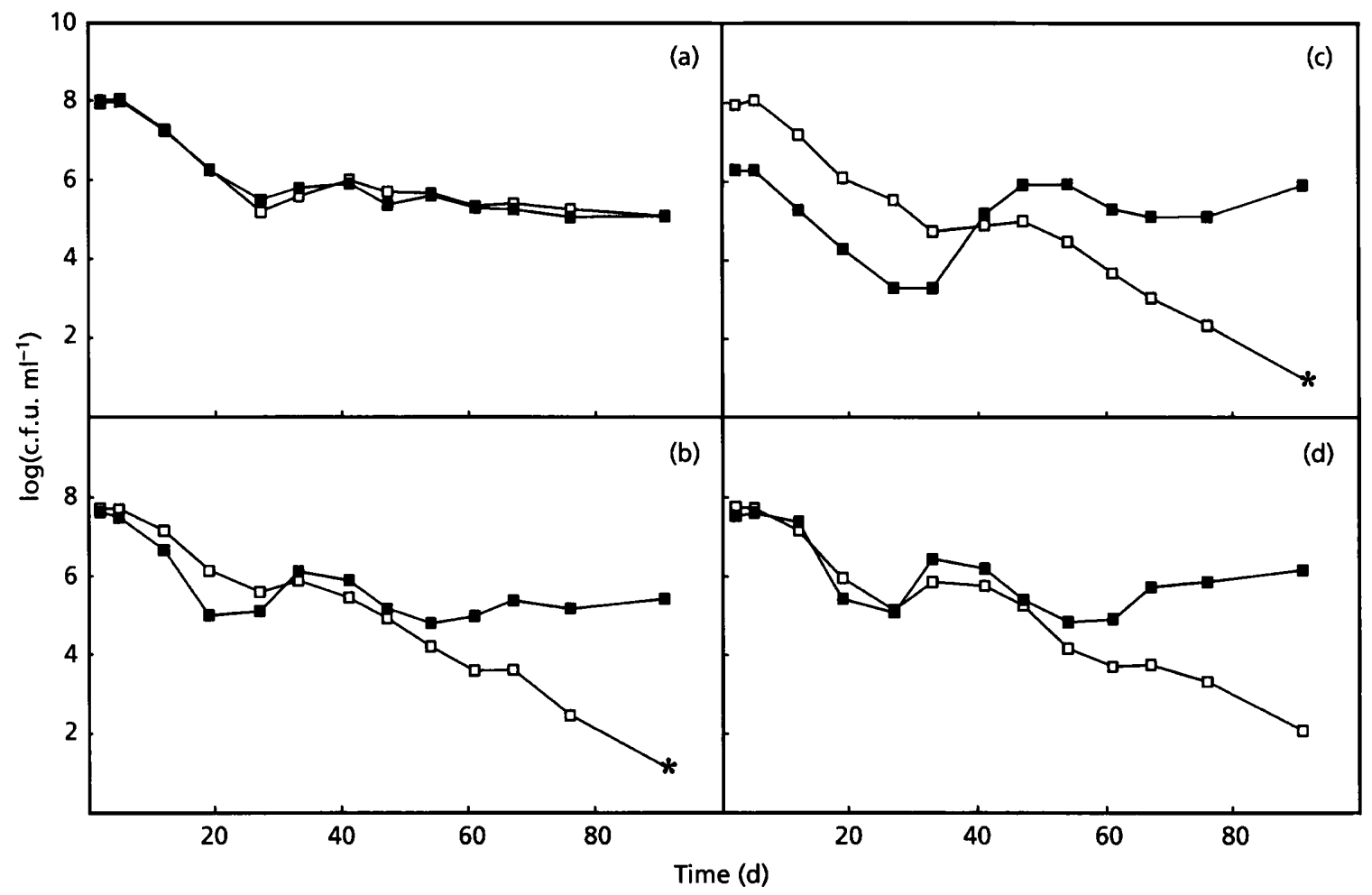

Fig. 6. Long-term viability of $\mathrm{KT} 2442(\square)$ and PSOM $(\square)$ when cells were starved for phosphate either separately (a) or in mixed cultures $(b-d)$. The latter experiments were performed by mixing $3 \mathrm{~d}$-starved mutant cells with $3 \mathrm{~d}$-starved wildtype cells in equal concentrations (b) or in the minority of mutant cells (c). Cells of both strains were also mixed in equal numbers (about $10^{5}$ c.f.u. $\mathrm{ml}^{-1}$ ) in fresh minimal medium such that both cell populations saturated at about $5 \times 10^{7}$ c.f.u. $\mathrm{ml}^{-1}$ (d). Asterisks indicate colony numbers too low to be detected when $100 \mu$ culture sample was plated directely. The graphs represent typical data obtained from three replicates.

re-introduced into minimal medium supplemented with limiting amounts of phosphorus, both cell populations reached $3 \times 10^{8}$ cells $\mathrm{ml}^{-1}$. Again, after an initial decrease in c.f.u. of both strains, the mutant resumed growth and eventually replaced the wild-type (Fig. 6d). These results were entirely independent of which strain carried the lux $A B-n p t$ cassette, indicating that the presence of these genes had no effect on the results (data not shown).

One possible explanation for the death of wild-type cells in mixed culture experiments could be that mutant cells produce a toxic product during phosphate starvation that kills wild-type cells. To test this possibility, wild-type cells were resuspended in sterile-filtered culture supernatant from a 2-month phosphate-starved PSOM culture. Regardless of whether these wild-type cells originated from exponentially growing or phosphate-starved (1 or 2 month) cultures, they remained viable. Moreover, upon re-addition of phosphate to these cultures, growth was reinitiated, suggesting that no inhibitory agent was released by PSOM cells during phosphate starvation.

\section{DISCUSSION}

In recent years, it has become evident from a number of studies that stationary cultures of bacteria display important activities which ensure survival under stressful conditions. Also, there have been many indications of complex regulatory circuits involved in controlling these activites, and in some cases overlaps between the different stress resistance programmes have been demonstrated. The elucidation of these survival programmes will improve our knowledge of bacterial growth and performance and, in particular, it will provide us with better tools to predict how bacteria live in their natural environments that are often stressful and nutrient-poor. The observations presented here demonstrate that some scenarios of nutrient starvation lead to complex cellular responses, both at the level of the physiology of individual cells and at the population level through selection of variant cells, which can eventually replace the original cell population due to improved fitness for the prevailing conditions. Thus, the example discussed here represents such a case of combined adaptation (controlled shift to a new physiological state) and evolution (selection for variant cells able to outgrow the wild-type cells).

\section{Survival during phosphate limitation}

The poor survival of $P$. putida KT2442 under conditions of phosphate starvation is in agreement with previous reports demonstrating that starvation for nutrients other than carbon (especially phosphate) results in much faster kinetics of death (Davis et al., 1986; Nyström et al., 1992; Siegele et al., 1993). It has been suggested that the major 
cause of cell death during prolonged starvation periods is an excessive loss of ribosomes (Davis et al., 1986). In recent studies it was demonstrated that in Vibrio sp. strain S14 ribosomes exist in large excess over the demand for protein synthesis during carbon starvation (Flärdh et al., 1992) and similar observations were reported for $P$. putida KT2442 (Givskov et al., 1994a). The presence of excess ribosomes has also been reported for the obligate intracellular parasite Rickettsia prowazekii which grows with a generation time of about $10 \mathrm{~h}$ in the cytoplasm of eukaryotic host cells (Pang \& Winkler, 1994).

The data presented here indicate that under phosphatelimiting conditions, $P$. putida KT2442 converts all available extracellular carbon into intracellular reserve materials (one of which is PHA) and initiates ribosome degradation in parallel with a decline in the rate of total protein synthesis. The reduction of the ATP pool at the beginning of the starvation period may directly affect the rate of protein synthesis, which in turn may induce ribosome degradation (in contrast to that observed for carbon starvation; Givskov et al., 1994a, b). Alternatively, the lack of phosphate may directly affect ribosome stability, which consequently will affect protein synthesis. Twenty-four hours after the onset of phosphate starvation, the number of ribosomes had declined to onetenth the normal amount during growth, whereas the rate of protein synthesis per living cell had declined to 0.02 of the rate during growth. This discrepancy may simply arise as a consequence of the stability of the ribosomes, which ensures a much higher concentration than is required for protein synthesis, which may be limited by factors other than ribosome number. Thus, a large fraction of the ribosomes are idle but activatable if conditions improve. Alternatively, all ribosomes may be engaged in protein synthesis but with reduced efficiency (chain growth rate). Assuming that the majority of ribosomes are actually functional, this may indicate a fivefold excess of protein synthesis capacity. At this point, however, it is important to emphasize that the in situ hybridization to rRNA used as a measure of the ribosome concentration in the cells does not provide any information on ribosomal activity or even conformation; if new forms of ribosomes arise under stresses such as described here, they will be recorded as ribosomes if they contain the probed rRNA sequences.

Phosphate-starved cells also developed resistance to environmental stress (Givskov et al., 1994a). Thus, apart from the absence of the stringent response, the early period of phosphate starvation strongly resembles carbon starvation with respect to protein synthesis capacity and stress resistance.

\section{ATP content during starvation}

$P$. putida KT2442 cells growing exponentially in minimal medium contained $1.4 \times 10^{-9} \mu \mathrm{g}$ ATP per cell. This value is within the range of $0.5 \times 10^{-9}-6.5 \times 10^{-9} \mu \mathrm{g}$ ATP per cell reported for seven marine bacteria (Hamilton \& Holm-Hansen, 1967), and very similar ATP levels have also been determined for the marine Vibrio Ant-300 $\left(1.5 \times 10^{-9} \mu \mathrm{g}\right.$ ATP per cell; Oliver \& Stringer, 1984;
Amy et al., 1983) and a marine Pseudomonas sp. $\left(0.65 \times 10^{-9} \mu \mathrm{g}\right.$ ATP per cell; Kurath \& Morita, 1983). In agreement with the same reports, we observed that under carbon starvation the ATP content per cell (c.f.u.) decreased by about $80 \%$ during the first $3 \mathrm{~d}$ and then remained stable for up to $74 \mathrm{~d}$. This is in sharp contrast to cells starved for phosphate, in which the cellular ATP level dropped to a level of $4 \times 10^{-11} \mu \mathrm{g}$ ATP per c.f.u. during the first $3 \mathrm{~d}$. However, during the next 3 weeks the ATP level increased back to the initial level of $1.3 \times 10^{-9} \mu \mathrm{g}$ per c.f.u. followed by a decrease to $0.6 \times 10^{-9} \mu \mathrm{g}$ per c.f.u., where it finally stabilized, interestingly at the same level also observed during long-term carbon starvation (Fig. 4). Since in actively growing cells, approximately $20 \%$ of the ATP is used for substrate transport (Stouthamer, 1973), it could be crucial for longterm starved cells to maintain certain ATP reserves (as was observed during long-term starvation) which would ensure that active transport systems are functional as soon as nutrients become available.

Chapman et al. (1971) suggested that starved cells lose viability due to a decline in energy charge. The extremely low levels of ATP observed during the initial period of phosphate starvation could indeed indicate that depletion of cellular energy is the actual cause of death. The subsequent increase in cellular ATP content to the level found in exponentially growing cells is then most likely accounted for by the utilization of nutrients that originate from dead cells. In addition to an increase in c.f.u. and cellular ATP levels (Fig. 3), we also observed that the rate of total protein synthesis was elevated in such cultures and that they contained cells with a very high ribosome content (data not shown). These results strongly support the hypothesis that after an initial death phase, phosphorus-containing nutrients become available again so that cell division can occur.

\section{Population changes during starvation}

Stationary-phase cultures are often considered to be rather static with very little or no variation in their population composition. The results presented in this paper demonstrate that in phosphate-deprived cultures of $P$. putida KT2442, mutants are selected that are able to grow and eventually replace the original population. Although mutants that took over phosphate-deprived cultures frequently exhibited changes in colony morphology and cell shape (mutants displaying the same changes as described for PSOM were observed in 9 out of 31 independent cultures after $35 \mathrm{~d}$ of phosphate starvation and in 12 further cultures after 6 months of starvation), this was not always the case. This indicates that mutations at different loci appear able to confer this phenotype, in agreement with the finding that the starvation survival of PSOM itself is indistinguishable from that of the wildtype (Fig. 6a). In fact, after 3 weeks of phosphate starvation, new mutants with a competitive advantage grew and took over cultures. When these 'second round' mutants were re-introduced into cultures containing PSOM, the latter rapidly died out (data not shown). This indicates that after repeated cycles of starvation additional 
mutations in PSOM are selected that give rise to mutants with further improved fitness for the condition of longterm phosphate starvation.

Population shifts have also been reported to occur in stationary phase LB cultures of E. coli (Zambrano et al., 1993; Kolter et al., 1993). In that study it was demonstrated that the mutants that take over the cultures carry mutations in rpoS, which encodes the stationary phase sigma factor $\sigma^{\mathrm{s}}$ (Tanaka et al., 1993). Is it possible that PSOM also carries a mutation in a putative rpos homologous gene? In E. coli, $\sigma^{\mathrm{S}}$ controls a regulon comprising at least 30 genes that are expressed in response to nutrient deprivation (McCann et al., 1991; Lange \& HenggeAronis, 1991). A comparison of the two-dimensional protein patterns of wild-type and mutants cells under the condition of phosphate starvation revealed only minor differences suggesting that no central regulator is inactivated in PSOM (data not shown). We also tested possible differences in the metabolic potentials between the two strains using the Biolog MicroPlate test system (Biolog Inc.) for strain identification, but no differences were observed (data not shown).

Although the precise mutation(s) in PSOM has not yet been identified, we suggest on the basis of the presented data that PSOM is better suited for the re-initiation of growth on those phosphorus-containing nutrients that become available after the majority of the initial population has died.

\section{ACKNOWLEDGEMENTS}

We are grateful to Linda Stabell for excellent technical assistance, to Dr G. Huisman for providing strain GPp104 and for helpful suggestions, and to Dr S. Kjelleberg for stimulating discussions. This work was supported by grants to SM from the Danish Center for Microbial Ecology, the Swedish Environmental Protection Agency and the EU Biotechnology Programme.

\section{REFERENCES}

Amy, P. S., Pauling, C. \& Morita, R. Y. (1983). Starvation-survival process of a marine Vibrio. Appl Environ Microbiol 45, 1041-1048.

Anba, J., Bidaud, M., Vasil, M. L. \& Lazdunski, A. (1990). Nucleotide sequence of the $P_{\text {seudomonas aeruginosa }}$ pho $B$ gene, the regulatory gene for the phosphate regulon. I Bacteriol 172, 4685-4689.

Bagdasarian, M., Lurz, B., Ruckert, B., Franklin, F. C. H., Bagdasarian, M. M., Frey, J. \& Timmis, K. N. (1981). Specific-purpose plasmid cloning vectors. II Broad host range, high copy number, RSF1010-derived vectors for gene cloning in Pseudomonas. Gene 16, 237-247.

Chapman, A. G., Fall, L. \& Atkinson, D. E. (1971). Adenylate energy charge in Escherichia coli during growth and starvation. $J$ Bacteriol 108, 1072-1086.

Clark, J. D. \& Maaløe, O. (1967). DNA replication and the cell division cycle in Escherichia coli. J Mol Biol 23, 99-112.

Davis, B. D., Luger, S. M. \& Tai, P. C. (1986). Role of ribosome degradation in the death of starved Escherichia coli cells. $J$ Bacteriol 166, 439-445.

Dawe, L. L. \& Penrose, W. R. (1978). 'Bactericidal' property of seawater: death or deliberation? Appl Environ Microbiol 35, 829-833.

De Weger, L. A., Dekkers, L. C., van der Bij, A. J. \& Lugtenberg, J. J. (1993). Use of phosphate-reporter bacteria to study phosphate limitation in the rhizosphere and bulk soil. Mol Plant-Microbe Interact 7, 32-38.

Flärdh, K., Cohen, P. S. \& Kjelleberg, S. (1992). Ribosomes exist in large excess over the apparent demand for protein synthesis during carbon starvation in marine Vibrio sp. strain CCUG 15956. J Bacteriol 174, 6780-6788.

Givskov, M., Eberl, L., Møller, S., Poulsen, L. K. \& Molin, S. (1994a). Response to nutrient starvation in Pseudomonas putida KT2442: analysis of general cross-protection, cell shape and macromolecular content. J Bacteriol 176, 7-14.

Givskov, M., Eberl, L. \& Molin, S. (1994b). Responses to nutrient starvation in Pseudomonas putida strain KT2442: two-dimensional electrophoretic analysis of starvation and stress inducible proteins. $J$ Bacteriol 176, $4816-4824$.

Hamilton, R. D. \& Holm-Hansen, O. (1967). Adenosine triphosphate content of marine bacteria. Limnol Oceanogr 12, 319-324.

Hancock, R. E. W., Poole, K. \& Benz, R. (1982). Outer membrane protein $\mathrm{P}$ of Pseudomonas aeruginosa: regulation by phosphate deficiency and formation of small anion-specific channels in lipid bilayer membranes. J Bacteriol 150, 730-738.

Holm-Hansen, O. \& Booth, C. R. (1966). The measurement of adenosine triphosphate in the ocean and its ecological significance. Limnol Oceanogr 11, 150-159.

Huijberts, G. N. M., de Rijk, T. C., de Waard, P. \& Eggink, G. (1994). ${ }^{13} \mathrm{C}-$ Nuclear magnetic resonance studies of Pseudomonas putida fatty acid metabolic routes involved in poly(3-hydroxyalkanoate) synthesis. J Bacteriol 176, 1661-1666.

Huisman, G. W., de Leeuw, O., Eggink, G. \& Witholt, B. (1989). Synthesis of poly-3-hydroxyalkanoates is a common feature of fluorescent pseudomonads. Appl Environ Microbiol 55, 1949-1954. Huisman, G. W., Wonink, E., Meima, R., Kazemier, B., Terpstra, P. \& Withold, B. (1991). Metabolism of poly(3-hydroxyalkanoates) (PHAs) by Pseudomonas oleovorans: identification and sequences of genes and function of the encoded proteins in the synthesis and degradation of PHA. J Biol Chem 266, 2191-2198.

Kato, J., Ito, A., Nikata, T. \& Ohtake, H. (1992). Phosphate taxis in Pseudomonas aeruginosa. J Bacteriol 174, 5149-5151.

Klemm, P. \& Christiansen, G. (1987). Three fim genes required for the regulation of length and mediation of adhesion of Escherichia coli type 1 fimbriae. Mol \& Gen Genet 208, 439-445.

Kogure, K., Simidu, U. \& Taga, N. (1979). A tentative direct microscopic method for counting living marine bacteria. Can $J$ Micrabiol 25, 415-420.

Kolter, R., Siegele, D. A. \& Tormo, A. (1993). The stationary phase of the bacterial life cycle. Annu Rev Microbiol 47, 855-874.

Kristensen, C. S., Eberl, L., Sanches-Romero, J. M., Givskov, M., Molin, S. \& de Lorenzo, V. (1995). Site-specific deletions of chromosomally located DNA segments with the multimer resolution system of broad-host-range plasmid RP4. J Bacteriol 177, $52-58$.

Kurath, G. \& Morita, R. Y. (1983). Starvation-survival physiological studies of a marine Pseudomonas sp. Appl Environ Microbiol 45, 1206-1211.

Lange, R. \& Hengge-Aronis, R. (1991). Identification of a central 
regulator of stationary-phase gene expression in Escherichia coli. Mol Microbiol 5, 49-59.

McCann, M. P., Kidwell, J. P. \& Matin, A. (1991). The putative $\sigma$ factor $\mathrm{KatF}$ has a central role in development of starvationmediated general resistance in Escherichia coli. J Bacteriol 173, 4188-4194.

Møller, S., Kristensen, C. S., Poulsen, L. K., Carstensen, J. M. \& Molin S. (1995). Bacterial growth on surfaces: automated image analysis for quantification of growth rate-related parameters. $A p p l$ Environ Microbiol 61, 741-748.

Neidhardt, F. C., Bloch, P. L. \& Smith, D. F. (1974). Culture medium for enterobacteria. $J$ Bacteriol 119, 736-747.

Nyström, T., Olssen, R. M. \& Kjelleberg, S. (1992). Survival, stress resistance and alterations in protein expression in the marine Vibrio sp. strain S14 during starvation for different individual nutrients. Appl Environ Microbiol 58, 55-65.

Oliver, J. D. \& Stringer, W. F. (1984). Lipid composition of a psychrophilic marine Vibrio sp. during starvation-induced morphogenesis. Appl Environ Microbiol 47, 461-466.

Ostroff, R. M. \& Vasil, M. L. (1987). Identification of a new phospholipase $\mathrm{C}$ activity by analysis of an insertional mutation in the hemolytic phospholipase $C$ structural gene of Pseudomonas aeruginosa. J Bacteriol 169, 4597-4601.

Pang, H. \& Winkler, H. H. (1994). The concentration of stable RNA in Rickettsia prowazekii. Mol Microbiol 12, 115-120.

Poole, K. \& Hancock, R. E. W. (1984). Phosphate transport in Pseudomonas aeruginosa: involvement of a periplasmatic phosphatebinding protein. Eur J Biocbem 144, 607-612.

Roth, W. G., Leckie, M. P. \& Dietzler, D. N. (1988). Restoration of colony-forming activity in osmotically stressed Escherichia coli by betaine. Appl Environ Microbiol 54, 3142-3146.

Sample, E. C., Soper, R. J. \& Raez, G. J. (1980). Reactions of phosphate fertilizers in soils. In The Role of Phosphate in Agriculture, pp. 263-310. Edited by F. E. Khasawneh, E. C. Sample \& E. J. Kamprath. Madison, WI: American Society of Agronomy.

Siegele, D. A., Almirón, M. \& Kolter, R. (1993). Approaches to the study of survival and death in stationary phase Escherichia coli. In Starvation in Bacteria, pp. 151-169. Edited by S. Kjelleberg. New York: Plenum Press.

Stouthamer, H. A. (1973). A theoretical study of the amount of ATP required for synthesis of microbial cell material. Antonie van Leeuwenboek J Microbiol Serol 39, 545-565.

Tanaka, K., Takayanasi, Y., Fujita, N., Ishihama, A. \& Takahashi, H. (1993). Heterogeneity of principal sigma factor in Escherichia coli: the $r p o S$ gene product $\sigma^{38}$, is a principal sigma factor of RNA polymerase in stationary phase Eschericbia coli. Proc Natl Acad Sci US $A$ 90, 3511-3515.

Wanner, B. (1987). Phosphate regulation of gene expression in $E$. coli. In Escherichia coli and Salmonella typhimurium: Cellular and Molecular Biology, Vol. 2, pp. 1326-1333. Edited by F. C. Neidhardt, J. L. Ingraham, B. Magasanik, K. B. Low, M. Schaechter \& H. E. Umbarger. Washington, DC: American Society for Microbiology.

Zambrano, M. M., Siegele, D. A., Almirón, M., Tormo, A. \& Kolter, R. (1993). Microbial competition: Escherichia coli mutants that take over stationary phase cultures. Science 259, 1757-1760.

Received 10 August 1995; revised 14 September 1995; accepted 26 September 1995. 